\title{
Sexual Harassment In The Workplace: Europe
}

John Lehman, (E-mail: john.lehman@uaf.edu), University of Alaska Fairbanks

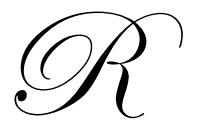

ebecca McDonald returned to her office in Leverkusen Germany still angry from her meeting with Bertina Knies in Human Resources. Rebecca had presented an open-and-shut sexual harassment complaint, clearly supported both by company policies and the Law, and Frau Knies had not only refused to do anything about it, but had not very politely insinuated that the whole thing was Rebecca's fault. The next step would probably be to appeal to Human Resources back in Detroit, since the Germans clearly had no understanding of the way things should work in a modern society.

Rebecca had grown up in Flint, Michigan, where her father was a supervisor for General Motors. As a first generation college student, Rebecca had received a scholarship from the University of Michigan, where she majored in mechanical engineering and then went to work for one of the major auto companies as a design engineer.

While women design engineers were a distinct minority in the auto business, there were enough that Rebecca did not feel out of place. While she was a student, she had taken classes which covered the history and legal issues involving women's advancement in what had historically been male professions, and she had been happy to find that the company was sensitive to women's needs, and that sexual harassment was not a problem.

After five years in Detroit, she was given the opportunity to work on a joint venture with Opa GmbH, a German subsidiary of her company. The new position would be a promotion, working with a team of German and American engineers designing a new sports car. The opportunity was especially attractive, since she was considering a career shift into management, taking advantage of the company policy to pay for an MBA for engineers whom it felt had the potential to be effective technical managers. The program was highly competitive, and the two years of international experience would significantly improve her chances, especially given the increasing number of multinational mergers in the auto industry, and the need to work with international partners. Besides, she had never been outside of the United States except for visits to company plants in Ontario.

Living in Germany had turned out to be a stressful experience. While everyone at work spoke English, it was difficult to get through the small problems of day to day life, since store clerks, plumbers, and most of the other people with whom she dealt spoke little if any English, and she spoke no German. Neighbors and other people with whom she dealt seemed often to be impolite, and life seemed to be governed by rules of which she was not aware. For example, one of her neighbors scolded her (in very poor English) the first week for the way she put out her trash one was required to separate out glass, paper, and cans, and dispose of them separately. Outside of CNN, there was little English available on television, only one English newspaper was available, and bookstores had a very limited selection in English. Fortunately most road signs were in the form of symbols, so at least driving was possible.

Another stressful aspect of living in Germany was the lack of respect for modesty. People sunbathed nude in parks; television and print advertisements featured nudity as well. Worst, because it impacted her work environment, was that unlike the United States, co-workers flaunted pictures of nude women at work - it was like a return to the bad old days of the 1950's where women couldn't enter male workplaces without being regarded as sexual objects.

The problem was not that her co-workers put up nude pictures, but rather that they brought objectionable material to work and read it in front of her. The most popular newspaper, Bild, had a picture of a nude woman on the front page every day (and probably worse inside). Other newspapers were no better; one or her colleagues even commented that he preferred to read Express because the nude pictures were of local girls. The final straw came when she went into her supervisor's office for a meeting and saw a copy of the magazine Der Spiegel on his desk, the cover 
of which reproduced a French painting of a topless woman waving a flag. At that point, she made an appointment with Human Resources to complain formally about having to work in an offensive work environment.

At her meeting with Bertina Knies in Human Resources, Rebecca cited the American company policy on sexual harassment (reproduced below). She pointed out that it clearly prohibited "posters, cartoons, pictures, or drawings" which had the "effect of interfering with an individual's work performance or creating an intimidating, hostile, or offensive work environment." Being exposed to pictures such as those in Bild or Der Spiegel in her opinion clearly met the definition of sexual harassment.

To Rebecca's dismay, Bertina was not at all supportive. She pointed out that in Germany unwelcome sexual advances or requests for favors were clearly unacceptable, but that Rebecca should not expect Germans to cater to her Puritan hang-ups. Bild, which Bertina personally deplored for its right-wing Christian politics, was after all, the most popular newspaper in Germany, and as Rebecca had observed, its competitors also featured nudity. The painting on the cover of Der Spiegel was one of the best known symbols of liberty in the world; no one who knew anything about art could consider it obscene. And basically, the Germans did not consider nudity offensive, and so long as no one asked Rebecca to do anything which she found unacceptable, she should not try to impose her values on others. For example, Turkish employees sometimes objected to working with women who did not wear head coverings or who wore short sleeves; imposing their religious strictures on those who did not share them would be a violation of freedom of thought and religion. Rebecca's request was no different than requiring women to wear headscarves so as not to offend Islamic immigrants. As an immigrant to Germany, Rebecca could dress however she liked, but should not expect Germans to adapt her old-fashioned values.

Clearly there was no point pursuing the issue with Human Resources in Leverkusen. Equally clearly, American courts long ago decided that depiction of nudity in the workplace (or anyplace else outside the home) was unacceptable. An appeal to Human Resources in Detroit would be the next step. However, before doing that, Rebecca had to consider both the chances of success, and the possible impact on her future.

\section{Excerpts from company policy on sexual harassment}

Sexual harassment is a form of misconduct that undermines the integrity of the employment relationship. All employees have the right to work in an environment free from all forms of discrimination and conduct which can be considered harassing, coercive, or disruptive, including sexual harassment. Anyone engaging in harassing conduct will be subject to discipline, ranging from a warning to termination.

Sexual harassment is defined as any unwanted physical, verbal or visual sexual advances,requests for sexual favors, and other sexually oriented conduct which is offensive or objectionable to the recipient, including, but not limited to: epithets, derogatory or suggestive comments, slurs or gestures and offensive posters, cartoons, pictures, or drawings.

When is conduct unwelcome or harassing? Unwelcome sexual advances (either verbal or physical), requests for favors and other verbal or physical conduct of a sexual nature constitute sexual harassment when:

- submission to such conduct is either an explicit or implicit term or condition of employment (e.g., promotion, training, timekeeping or overtime assignments)

- submission to or rejection of the conduct is used as a basis for making employment decisions (hiring, promotion, termination)

- the conduct has the purpose or effect of interfering with an individual's work performance or creating an intimidating, hostile, or offensive work environment 


\section{QUESTIONS}

1. In a US work environment, would reading a newspaper or magazine with nude pictures on the cover be sexual harassment?

2. If so, would it be sexual harassment in Germany when working for the same company? Why or why not?

3. Frau Knies argues that Rebecca's request to prohibit Germans from reading newspapers which offend her is no different than prohibiting German women from dressing in ways which offend Islamic immigrants working in the plant. Is this a valid argument? Why or why not?

4. What should Rebecca do?

5. What should Rebecca's company have done to prevent this problem? 


\section{Teaching Note Sexual Harassment In The Workplace: Europe}

\section{SYNOPSIS}

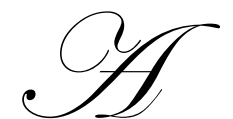

n American engineer assigned to work at a company subsidiary in Germany finds the nude pictures on the front pages of German mass-market newspapers offensive. Her complaints to the German human resources office that reading such material at work violates corporate sexual harassment policies results in a lecture on tolerance and religious freedom rather than enforcement of the sexual harassment policy.

\section{OBJECTIVES}

The case focuses on the dilemmas (both personal and legal) caused in multi-cultural organizations when different cultures attach differing ethical valuations to aspects of daily life. In this case, the issue is public display of nudity, which is considered offensive in North America but natural in parts of northern Europe. Related issues are culture shock and the need for intercultural training for employees being sent on foreign assignments.

\section{TEACHING STRATEGY}

In teaching this case, a common student misunderstanding is that the newspapers and magazines under discussion are "porn" or "nude" magazines; they are, in contrast, ordinary mass-market periodicals. In terms of US equivalents, Bild is approximately equivalent to USA Today, Express to the New York Post and Der Spiegel to Time. This is important, since Rebecca's coworkers are reading their ordinary newspapers and news-magazines, not the German equivalent of Playboy or Hustler.

This misunderstanding, which usually surfaces very quickly in the discussion, can be used to point out the cultural gulf between the US and Germany with respect to nudity. Even after reading the specific descriptions of these periodicals in the case, American students automatically assume that the German workers must be reading specialty "men's" magazines rather than the equivalent of USA Today.

Once students realize this cultural difference, the discussion can move into how employees from one culture can learn to function in another. The major conceptual issue here is the extent o which multinational companies should attempt to develop common ethical and personnel standards across national boundaries. The major associated legal issue is that of extraterritoriality (discussed in the analysis section below).

One of the factors in Rebecca's inability to accept the behavior of her German coworkers is almost certainly culture shock. Culture shock is a normal response when moving to a new cultural environment. It is caused by the brain's attempts to deal with sensory inputs which do not correspond to normal patterns. Culture shock usually manifests itself as a series of elations and depressions. The normal stages of Culture Shock are:

1. Arrival fascination

2. Initial culture shock

3. Surface adjustment

4. Mental isolation

5. Integration/Acceptance

Courses For Which This Case Is Appropriate: International business, international ethics, business ethics, human resources. 
6. Return anxiety

7. Re-entry shock/Reintegration

Stages 2 (initial culture shock) and 4 (mental isolation) are usually accompanied by some level of depression, often severe. Stage 2 normally lasts a week or two; stage four can last much longer. A fairly high proportion of those who live abroad never get beyond one or the other of these stages; failure in foreign managerial assignments is often associated with getting stuck in one or the other of these stages. One of the characteristics of both of these "down" stages is fixating on aspects of the foreign culture, often minor in themselves, which assume tremendous significance to the sufferer.

\section{ANALYSIS (CASE QUESTIONS)}

Q: $\quad$ In a US work environment, would reading a newspaper or magazine with nude pictures on the cover be sexual harassment?

A: Clearly the answer is yes. The US Supreme Court decision "Teresa Harris v. Forklift Systems, Inc." is perhaps the clearest statement of the law (114 S. Ct. 367 (1993).

Q: If so, would it be sexual harassment in Germany when working for the same company? Why or why not?

A: Legally, no. US law does not extend outside the US (the principle of extraterritoriality has been rejected in international law since the 1940's). In Germany, sexual harassment in the form of quid pro quo propositions is prohibited, but nudity does not have the strong links with sex which it has in the US.

Whether the company should attempt to have a common sexual harassment policy across all of its national branches is a management decision. The case points out some of the problems in trying to do this without understanding local cultures (i.e. do they really wish to ban possession of newspapers at work).

Q: $\quad$ Mrs. Knies argues that Rebecca's request to prohibit Germans from reading newspapers which offend her is no different than prohibiting German women from dressing in ways which offend Islamic immigrants working in the plant. Is this a valid argument? Why or why not?

A: The German argument is that American phobia about nudity is religiously based (primarily in Calvinism, which was not influential in Germany). A counter argument is that all forms of Christianity were historically intolerant of nudity, and that German tolerance of it is a cultural development which arose from natural health movements over the late nineteenth and twentieth century. Both views are true.

Q: What should Rebecca do?

A: If she wants to have a future as a manager in an international environment, she will clearly need to distinguish between real ethical issues and intercultural miscommunication and misunderstanding. There is a high probability that she is dealing with the impact of culture shock. Learning more about German culture and society would help. Patrick Schmidt's book (additional resources) is an example of training material intended for Americans working in Germany.

Q: What should Rebecca's company have done to prevent this problem?

A: This case illustrates the need for intercultural training before deploying employees overseas. Approximately $40 \%$ of expatriate assignments fail, in large part due to cultural shock or intercultural miscommunication (for either the employee or family members). 


\section{CONCLUSION}

This case illustrates the need for intercultural training before deploying employees overseas, even to countries which are culturally very similar to the United States. In particular, it illustrates how small differences can be magnified by the unconscious impact of cultural shock, causing expatriate workers to fixate on issues which are not important. It also illustrates how activities which are considered normal in one culture can be interpreted as aggressively immoral in another culture, leading to both confrontation and mutual incomprehension. While most contemporary examples come from conflicts between Western and Islamic views of behavior, this case illustrates the same process taking place between members of two very similar cultures.

\section{ADDITIONAL RESOURCES}

Current editions (in German) of the publications referred to in the text are available on the web at:

$\begin{array}{lll}\text { Bild } & \underline{w w w . b i l d . d e} & \begin{array}{l}\text { National tabloid newspaper } \\ \text { Express }\end{array} \\ \text { Der Spiegel } & \underline{w w w . e x p r e s s . d e} & \begin{array}{l}\text { Local tabloid newspaper } \\ \text { National news magazine }\end{array}\end{array}$

\section{REFERENCE MATERIAL ON CULTURE SHOCK AND GERMAN CULTURE}

- $\quad$ AHA International recommendations for students studying abroad: http://www.ahaintl.org/aha gen/handbook 7 .

- $\quad$ Consortium for International Education \& Multicultural Studies http://www.worldwide.edu/travel_planner/culture_shock.html.

- $\quad$ Patrick Schmidt, Understanding American and German Business Cultures, Meridian World Press (2001) ISBN: 0968529305. 